\title{
Communicative Planning Potentials of Housing Estate Development Process in England: A Case Study from Dickens Heath New Settlement
}

\author{
Perera, $\mathbf{U}^{1}$ \\ ${ }^{1}$ Department of Estate Management and Valuation, University of Sri Jayewardenepura, Sri Lanka.
}

\begin{abstract}
In the 21 st century, societies are increasingly multi-sided with secular interests, making urban issues complex, dynamic and unable to be solved by a single institution. In this context, communicative planning propagates that the pathway to finding sustainable solutions for complex social problems would come from stakeholder participation and the identification of shared interests among such secular interests (consensus building). Rooted to Habermasian communicative rationality, communicative planning argues, stakeholder participation can ponder not only the scientific knowledge but also emotive and moral knowledge of lay actors such as local communities to inform planning better. In this respect, the paper explores the extent to which communicative planning works for the housing estate delivery process in England. With key pieces of planning legislation, mandating community engagement in all forms of physical development, England is considered one of the highest forms of legal backing for communicative planning. Meanwhile, housing provision is one of the complex and critical planning concerns of all cities. Dickens Heath New Settlement (DHNS) - a large scale housing estate development in the West Midlands of England, has been selected as the case study here to investigate this communicative planning potential in the context of housing estate development. Following qualitative methods, data were collected through sixty in-depth interviews with DHNS residents, community groups, master planners and local authority planners, and documentary evidence such as the DHNS master plan and local planning documents. The findings highlighted that communicative planning had a negligible effect at the conceptual planning stage of DHNS, but accrued relatively positive outcomes at the mature design, development and management phases of the estate development. These are valuable insights for housing development practice, communicative planning theory and practice, and reflect on Sustainable Development Goal (SDG) 11 - sustainable cities and communities in the context of England.
\end{abstract}

Keywords: Communicative planning, Emotive knowledge, Power, Consensus-building, housing, England, SDG-11

\section{Introduction}

Rapid urbanisation is a characteristic of the 21st century (World Bank, 2020), while societies live as multi-sided and secular interest groups (Healey, 2015). Economic, environmental, and social problems are complex where a single institution seems incapable of correctly identifying them, let alone addressing them (Verster, 2020; Klasic \& Lubell, 2020). Change in every spectrum challenges the sustainability of the systems on which we depend. Consequently, delivering planned outcomes for sustainable urban living has become a daunting task of planning (Zaidan \& Abulibdeh, 2020; Rydin et al., 2012). Communicative planning argues that sustainable solutions to

*Corresponding Author

https://orcid.org/0000-0002-2092-9197

e-mail: tgup@sjp.ac.llk

DOI: http://doi.org/10.4038/bhumi.v8i1.76 
planning problems under such context can pragmatically be brought by stakeholder engagement and building shared understanding among them (see, for example, Perera \& Mensah, 2019, Vos, 2007). Underpinned by the seminal work of Jürgen Habermas communicative rationality (Habermas, 1984, 1981, 1979), the philosophy of communicative planning calls all forms of knowledge provisional. Thus, not only scientific knowledge of experts but also emotive and moral knowledge (values or interests; Healey, 2006) of laymen should be empowered to govern the plan decision making into building shared understanding among all stakeholders.

Therefore, this article aims to investigate communicative planning potential (in terms of both process and outcome) in the context of housing estate development in England. In other words, it analyses the extent to which residents' voices can be brought in to plan decision making in order to generate 'meaningful' or 'sustainable' outcomes of housing estates. The housing estate development process referred to in the study include all its' stages covering preliminary planning approval, master planning (detail design), development and neighbourhood management stages (Ratcliffe et al., 2009).

England's planning legislation ${ }^{i}$ provides more significant emphasis on community engagement. Nevertheless, the housing estate development process in England is often challenged by the nexus of planning matters such as further releasing greenbelt land for new housing, new developments piggybacking on existing infrastructure, quality innovation, housing mix, mixed communities, housing affordability and the like (see, for example, Leishman et al., 2020; Preece, et al, 2020; Williams et al, 2019; Barker, 2006). Therefore, if communicative planning demonstrates a potential to build shared understanding, it can be mobilised effectively to deliver sustainable urban living experiences within housing estates in England.

A plethora of literature is available on communicative planning in the field of urban planning, sustainability, housing, transport, health and the like. Yet studies that comprehensively look into its practice cover all its theoretical perspectives (i.e. holistic communicative planning process covering knowledge, power relations, governance for consensus-building), and the housing estate context covers all the development stages that enable capturing communicative planning effects over time are limited.

Dickens Heath New Settlement (DHNS) in West Midlands of England is a large-scale housing estate development verbalised as a 'Sustainable Best Practice', and the community were primarily involved in the planning process. Planned in 1991, DHNS holds enough maturity as a case study for the researcher to observe the effects of communicative planning on the housing delivery process. As an explanatory case study (how and why some conditions came to be; Yin, 2014: 238), the paper investigates how DHNS residents manage their power relations during communicative planning exercises (power aspect in communicative planning), to what extent (under such power relations) the process has been capable of generating relevant lay knowledge (knowledge aspect in communicative planning) and how such knowledge was governed within planning decision making process to generate 'meaningful' or 
'sustainable' housing estate outcomes (consensus-building aspect in communicative planning).

Following qualitative methods, data were collected through in-depth interviews and relevant documents and the analysis was done based on the themes of the theoretical aspects discussed under communicative planning, i.e., power, knowledge, and consensus-building. This work will advance the literature on both communicative planning and housing, highlighting the effective and ineffective aspects of the communicative planning framework in England and thus informing the relevant planning policy areas to improve. Overall, it reflects the practice and possibilities of Sustainable Development Goal (SDG) 11Sustainable Cities and Communities in the context of New Settlements in England.

\section{Theory of communicative planning - the status quo}

Communicative planning (Brownill, 2009), otherwise known as collaborative governance (Florini, 2019; Healey, 2006) deliberative planning, (Forester, 1999), or inclusionary discourse (Healey, 2006) advocates societies to govern themselves and for the world as a whole to cope with transnational challenges through cross-sector collaborations across governments, businesses, civil society groups and local communities (Florini, 2019, p. 34).

Communicative planning is in line with the argument adapted from the critical theory of communicative rationality presented by Jürgen Habermas from the 1980s (Habermas, 1984, 1981, 1979) and John Forester from the early 1990s (Forester, 1999, 1989). The overarching rationale here is that moral and emotive (lay) knowledge of local communities should be given the same privilege during planning decision making with that of scientific knowledge brought in by other stakeholders. Knowledge is constructed through social processes, where scientific knowledge provides only a part of the basis for good judgement and sound decision-making (Khakee et al., 2000; Habermas, 1984). This argument implies that there is no universal truth about space, only a series of occurrences where space and society mutually construct each other (Natarajan, 2017, p. 1).

As the present-day economic, environmental and social problems are complex, dynamic in a way, a single institution is unable to handle, the present literature on planning, development, energy and housing tends to see the relevance of the communicative planning argument in searching for a new social order with different capacity (Natarajan, 2017, Innes \& Booher, 2004), sustainability (Perera \& Mensah, 2019, Vos, 2007) or positive change (Rydin, 2007; Healey, 2006).

\subsection{Power in communicative planning}

Power generally implies the bias or asymmetric (Lukes, 1986) between actors' relationships consequent to (power to) authority, resources (allocative) and discursive legitimacy, as some actors possess power over other actors (Purdy, 2012; Hardy \& Phillips, 1998). Habermas' stance on power claims it to be a distortive factor for communicative actions and urges communicative planning to be undertaken in a power-neutral setting to achieve its anticipation. The critical work on communicative planning used Habermas' claim to contest the practicality of communicative planning; communicative planning 
requiring power neutralisation can be a lofty ideal amidst market forces having the ability to exert their agency and could suppress the voices of the public (Gunder, 2010; Purcell, 2009, Cooke \& Kothari, 2001).

Following the Foucauldian view (1984, 1991) - power is unavoidable and not always evil - the contemporary communicative planning theory attempts to explore ways to deal with it and mobilise it as a modality of change (See, for example, Wolff, 2020; Brownill \& Carpenter, 2007; Albrechts, 2003). Among these, Albrechts (2003, p. 916) strategic framework, which recognises different rationalities that actors use to exercise power in the planning process (Table 1), is particularly used to analyse the systems of power which exist within England's housing delivery process. Within a communicative planning process, power exists at the availability of communicative planning platform, and actors are recognised for such participation (commutative rationality); actors possessing collective interests (value rationality), within the design of the communicative planning platform (instrumental rationality) and the actors forming alliances to exercise power over other actors (strategic rationality). Identifying these power rationalities would highlight power's tensions for communicative actions (Brownill \& Carpenter, 2007).

\subsection{Emotive knowledge in communicative planning}

Emotive knowledge holds distinctive attributes of being dramaturgical expressive, self-representation, and oriented to understand the subjective world - and thus less manipulative and closer to the truthfulness of selfinterests or subjective meanings (Habermas, 1984). Such knowledge is produced tacitly by laymen to the subject through their experience. Small wins, trust-building among stakeholders and communicative planning facilitators, leadership, and place-related attachments of communities are essential motives for the public to participate in communicative actions (Ansell \& Gash, 2008; Booher \& Innes, 2002) and convey their true interests. Recasting Habermasian theory, the contemporary communicative planning theory attempts to specify more; whether all speech acts of laymen counts as emotive knowledge and how such different emotive knowledge is relevant to various decision making (consensus building). Natarajan (2017); Alexander (2008); Rydin (2007); Friedmann's (1987) work are of particular interest concerning this. The conclusions arrived that lay knowledge could be in different typologies and planners need to know when and where to apply them for planning decision-making (Alexander, 2008, Rydin, 2007; Khakee et al., 2000). Table 2 shows how each emotive knowledge typology is relevant to a different state of planning of local environments. For example, one's current experience in the local environment would be pertinent to understand its present socio-economic and environmental context or outcome of a previously planned action.

\subsection{Consensus building in communicative planning}

Consensus building refers to the decision-making aspect of the communicative planning process. This stage discusses and validates emotive knowledge, power-sharing, negotiating, and confronting experts with lay participants, assessing findings, creating new ideas and implications of each frame of reference (Innes \& Booher, 1999). 
Table 1: Forms of Power in a communicative planning process

\begin{tabular}{|l|l|}
\hline $\begin{array}{l}\text { Power forms in } \\
\text { communicative planning }\end{array}$ & Description \\
\hline Commutative rationality & $\begin{array}{l}\text { Recognises and accepts platform for actors to discuss } \\
\text { shared problems and to reflect on ways out of these } \\
\text { problems }\end{array}$ \\
\hline Value rationality & $\begin{array}{l}\text { Actor's design shared futures; to develop and } \\
\text { promote common assets }\end{array}$ \\
\hline Instrumental rationality & $\begin{array}{l}\text { The best way to solve problems to achieve the desired } \\
\text { future; including all stakeholders, including } \\
\text { troublesome ones, encouraging formal and informal } \\
\text { interaction, accepting negotiation as a time- } \\
\text { consuming process, two-way communication } \\
\text { between planners and all other stakeholders, } \\
\text { accountability and transparency of the process, } \\
\text { leadership, and stakeholder involvement in designing } \\
\text { the communicative planning process. }\end{array}$ \\
\hline Strategic rationality & $\begin{array}{l}\text { Actors construct certain initial alliances to arm } \\
\text { themselves against the prevailing power structure. }\end{array}$ \\
\hline
\end{tabular}

Source: Adapted from Albrechts (2003)

Table 2: Types of lay knowledge and relevance to the plan decision making

\begin{tabular}{|l|l|}
\hline $\begin{array}{l}\text { Typology of lay } \\
\text { knowledge }\end{array}$ & $\begin{array}{l}\text { Relevance to the plan decision making (consensus } \\
\text { building) }\end{array}$ \\
\hline Experiential /empirical & $\begin{array}{l}\text { To understand empirical account of socio-economic and } \\
\text { environmental situations or outcomes as a result of } \\
\text { planning }\end{array}$ \\
\hline Predictive & $\begin{array}{l}\text { To understand the prediction of a future scenario under } \\
\text { trend conditions }\end{array}$ \\
\hline Process & $\begin{array}{l}\text { To understand social, economic, environmental processes } \\
\text { and planning processes affecting society }\end{array}$ \\
\hline Normative & To understand desired goals for planning by the society \\
\hline
\end{tabular}

Source: Adapted from Rydin (2007)

The aim of meaningful consensus should be to build shared understanding and not one or few participants (Habermas, 1984). Often the primary critique put forward by the critical work on communicative planning is also about the patronage type relationships that actors exercise at the consensusbuilding - those manipulate 'emotive' knowledge to be compatible with bureaucratic planning (See, for example, Cooke \& Kothari, 2001).
Among limited research available to answer how emotive knowledge should be governed in communicative planning amidst power relations of actors to attain meaningful (sustainable) solutions, works by Healey (2006) and Newman (2001) are of particular importance. For "meaningful" consensus building, planned decision making should be governed in the style of Inclusionary argumentation which 
considers the emotive knowledge of all actors.

Consensus building in the mode of Inclusionary argumentation has the traits such as horizontal network building, new ideas, considering ideas generated through all community members, rights, and opportunities to challenge policies as they are developed - making sense together but living differently (Healey, 1999). Healey also claims entrepreneurial consensus as a mode of governance favouring communicative planning but recognises representative democracy, pluralist democracy, corporatism, clientelism, criteria-driven approach as hierarchical decision-making modes that rely on knowledge of limited actors (Table 3).

Table 3: Governance type in plan decision-making

\begin{tabular}{|l|l|}
\hline $\begin{array}{l}\text { Governance } \\
\text { type }\end{array}$ & Rationale \\
\hline $\begin{array}{l}\text { Representative } \\
\text { democracy }\end{array}$ & $\begin{array}{l}\text { Governments are created on behalf of the people, and } \\
\text { they are elected representatives of the public. }\end{array}$ \\
\hline $\begin{array}{l}\text { Pluralist } \\
\text { democracy }\end{array}$ & $\begin{array}{l}\text { A society is composed of many different interest } \\
\text { groups; all competing to define the agenda for } \\
\text { government actions. }\end{array}$ \\
\hline Corporatism & $\begin{array}{l}\text { A good decision is the one that best achieves the public } \\
\text { interest as defined by the corporate alliances. }\end{array}$ \\
\hline Clientelism & $\begin{array}{l}\text { Politicians and government officials are involved in an } \\
\text { interactive relationship through social networks. This } \\
\text { mode of governance substitutes the social network of } \\
\text { family, friendship, fiefdom and business to allocate } \\
\text { and distribute resources. }\end{array}$ \\
\hline $\begin{array}{l}\text { Criteria-driven } \\
\text { approach }\end{array}$ & $\begin{array}{l}\text { A good decision achieves agreed government } \\
\text { objectives, regulatory criteria and performance targets } \\
\text { as efficiently and as accountable as possible. }\end{array}$ \\
\hline $\begin{array}{l}\text { Entrepreneurial } \\
\text { consensus }\end{array}$ & $\begin{array}{l}\text { Local alliances (partnership building activities) with } \\
\text { development agendas can be considered a form of } \\
\text { local corporatism. These tend to draw upon the } \\
\text { knowledge of local business and political elites. The } \\
\text { informal nature of such alliances contributes new ideas } \\
\text { to the local arenas. }\end{array}$ \\
\hline $\begin{array}{l}\text { Inclusionary } \\
\text { argumentation } \\
\text { of all members of a political community and that these } \\
\text { members have the opportunity to express their views } \\
\text { and challenge the decisions made on their behalf } \\
\text { through rights and opportunities to challenge policies. }\end{array}$ \\
\hline
\end{tabular}

Source: adapted from Healey (2006) 
Besides, any consensus will be under pressure when circumstances change, new stakeholders appear, and new fractures occur. Thus it is an evolving process that could have second and third-order effects, producing new relationships, new practices, and new ideas better than the current agreement (Klasic \& Lubell, 2020; Innes \& Booher, 1999).

\subsection{Research gaps, study proponents and conceptual framework}

The plethora of empirical studies inquiring the potential of communicative planning in development have seemingly polarised on aspects of power; extent to which the 'voice' of communities is recognised and heard within the planning process (Villanueva. et.al, 2017; Inch, 2015; Albrechts, 2003), and whether power and different rationalities form tensions on public participation (Brownill \& Carpenter, 2007). The implied presumption is that handling power and enabling communities to participate would per se allow the shared view of the world. As understood by the review of communicative planning literature, achieving shared understanding also requires the process to generate 'relevant' emotive knowledge as well as govern them for 'meaningful' consensus. Moreover, the empirical grounding of most research on communicative planning is more shortterm focused, testing community engagement as a one-time event only. Consequently, the fact that both communicative planning and its outcomes are considered an evolving process (Innes $\&$ Booher, 1999) is largely ignored.

This study, framing the examination around the contemporary status quo of communicative planning theory, investigates the communicative planning potentials for housing delivery by consolidating all relevant aspects; power, knowledge, and consensus-building. Following the proposition that power is unavoidable (Foucault, 1980, 1983), firstly, Albrechts' (2003) framework was used to understand different power rationalities that the communities have been acquiring to empower their voices about the DHNS housing development. Secondly, Rydin's (2007) knowledge typology framework was employed to test public participation in DHNS, in the light of those being relevant emotive knowledge to make the housing estate 'liveable' for residents. Finally, based on Healey's (2006) framework for governance modes in decision making and supposedly inclusionary argumentation that complies largely with communicative planning aims, the study looked at the extent to which housing delivery decisions have been governed through communicative planning.

\section{Methods and Materials}

Investigating communicative planning potential in housing estate development requires an in-depth analysis of the resident's overtime engagement with planning. In order to illuminate these conditions in real life, the study adopted a single and explanatory case study approach with a qualitative strategy (Yin, 2014; Løkke, \& Sørensen, 2014, Ragin, 2004). One of England's large-scale housing development projects - DHNS was selected as the case study. DHNS provides a coherent scenario suitable to understand a complex phenomenon (Johansson, 2007; Flyvbjerg, 2006) that align with the study's requirements. England has policy support for communicative planning as the key pieces of the country's planning legislation $^{1}$ on local development, providing mandatory platforms for local communities, lobby groups, businesses and the like, to engage in plan decisionmaking, including housing development. DHNS is considered one of the best practices of housing delivery with a significant community engagement (Rudlin \& Falk, 2009; TCPA, 2007). Bounded by woodlands and rail lines, DHNS, as a case, has an identifiable geographical boundary. Having commenced in 1991, it holds sufficient maturity to investigate the timely effects of 
communicative planning deal with housing estate development.

Primary data of the case study were collected from sixty in-depth interviews with residents and community groups, local council planners and officials, master planners and market actors (landowners, strategic promoters, developers) who had been engaged with the DHNS development. The interviews were held over 18 months between 2018 and 2019. They were asked how communicative planning actions produced different emotive knowledge, how power existed, built, and dealt with communicative actions, and how the emotive knowledge produced by residents was governed in the plan decision-making process. The case study also drew data from relevant documents from the local council - master plan details and public comments received for planning applications.

In order to enable the inquiry of over time effects of communicative planning on housing delivery, communicative actions of residents and the consensus-building in housing delivery is looked at all stages of the DHNS development from 1991-2019; preliminary planning approval stage (land and housing number allocation stage), detailed design and development stage (master planning and construction) and neighbourhood management stage (postdevelopment stage). Consequently, a methodical challenge arose having to recall respondents' memories associated with different stages of DHNS development. Validating interview data with validation questions (Locander et al., 1976), triangulating data with documentary evidence (Yin, 2014), selecting interviewees who had been closely associated with DHNS development (e.g. pioneer residents, planners who conceptualise the project since inception likewise) were employed to manage such challenge. Data analysis of the study followed thematic analysis (Bryman, 2016). For this purpose, data coding was guided by the theoretical propositions of communicative planning (Mihas, 2019,
Bryman, 2016); power, knowledge and consensus-building.

\section{Context of the Study}

\subsection{Dickens Heath New Settlement}

DHNS, which started in 1991, is located within 57 acres in Solihull Metropolitan Borough Council (SMBC), West Midlands. This has been a settlement that has aimed to provide sustainable and affordable housing for then-emerging middle-class, service sector households that had emerged following the region's economic restructuring during the 1970s80s. Yet DHNS experienced many outside processes challenging these initial aims. Initially, the estate was planned for 850 houses for a population of 4000. From 2019 onwards, market forces continued growing DHNS up to 2000 houses approving several other planning applications since 1991, which released land for further growth from the year 2000 onwards. Detailed designing with master planning for DHNS took place from 19911994 for outer areas and the central parts of the estate in 2003 (Figure 1). Dickens Heath Management Company - the developer's management arm was responsible for providing common area infrastructure and maintenance. Typically, the rest of the neighbourhood was managed by the council (SMBC).

Sustainable Urban Living Pressures The estate was designed and developed with 'sustainable' housing credentials. DHNS was awarded the Best Mixed-Use Development by the UK property awards in 2009 (See, for example, Rudlin and Falk, 2009; TCPA, 2007). Nevertheless, the settlement continued to encounter complex and dynamic tensions characteristic of the $21^{\text {st }}$-century on housing delivery. Different externalities and processes came from regional differences in housing and labour markets, financialisation of housing and capital liquidity, and changes to the national planning policies from time to time (i.e. Planning Policy Guidance 3, 2000; National Planning Policy Framework, 


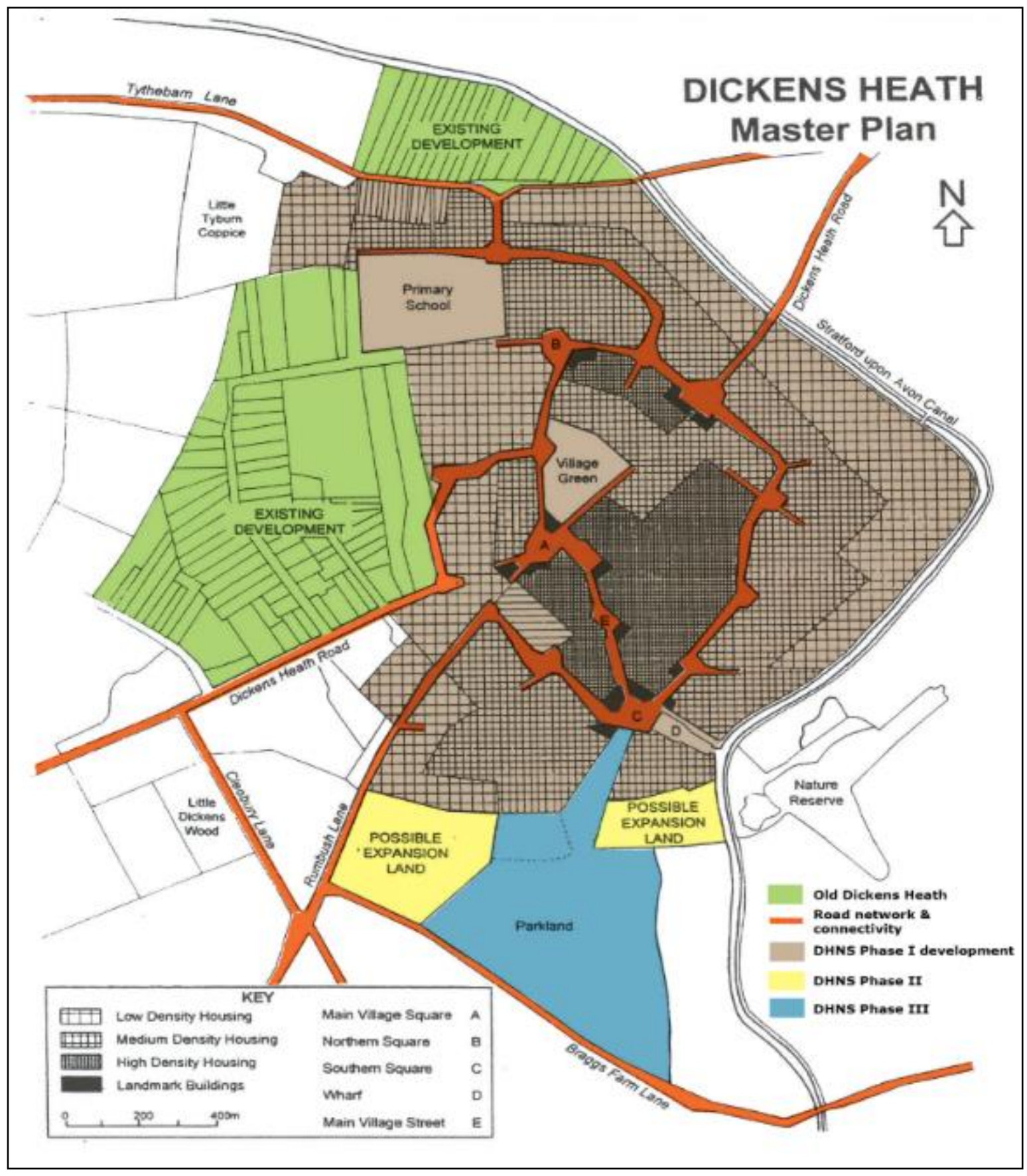

Figure 1: Dickens Heath New Settlement Master Plan Source: SMBC (undated)

2012, 2019). Those made an impact on the DHNS communities in terms of development pressure to increase the number of houses continuously, armslength global investments increasing the housing prices, infrastructure and service pressure, high traffic and flooding threats, development-held up construction sites during the great recession in 2008-2010, chang in the scale and class to whom the housing in DHNS could afford to and the like.
It is mainly against these pressures that the residents in DHNS have been actively engaged with the developers' consortium ${ }^{\text {ii }}$ and the council concerning DHNS housing delivery. The community, engaged with planning in DHNS represents a 'strong' community; $80 \%$ of DHNS population were White British engaged in professional, managerial or administrative occupations and $49.5 \%$ of them possessed 
a degree or professional educational background (ONS, 2019).

\section{Results and findings}

\subsection{Residents' rationalities for Power}

From the start of the DHNS development, different intermingled power rationalities (Albrechts, 2003) evolved, empowering the DHNS community in participating in the planning process.

Communicative and instrumental rationality; the statutory communicative planning platforms provided through planning legislation and SMBC development planning policies enabled DHNS residents to make their voices on the time-to-time development of DHNS heard. Depending on the scale (number of housing units) of the planning application that came forward, these platforms varied from public exhibitions, public comment forms - manual or online, planning inquiries, public examinations, the like.

Since the 2007 aftermath of development, the SMBC appointed a neighbourhood coordinator (for the Blyth Ward in which DHNS is situated) as the first call for communities to liaise with them regarding neighbourhood concerns - infrastructure interruptions, highway issues, village management issues, traffic problems, community development etc. [SMBC Council Officer]. This enabled both formal and informal interactions to convey people's interest even when meeting on the road. It was a two-way communication (Albrechts, 2003), having the neighbourhood coordinator communicate to residents about the council's response to their problems [Blyth ward Neighbourhood Coordinator].

Besides, the residents also had the opportunity to contribute to conventional representative democracy; communicating their 'interests' via the elected council member to the Blyth ward of SMBC [SMBC Councillior]. Together, these gave the DHNS residents typical power to authority (Purdy, 2012; Hardy \& Phillips,
1998) in conveying their "problems and interests' on housing estate development and management to the plan decision making.

Building power with strategic rationality; the residents' reflexively monitored the 'effectiveness' of these given statutory platforms. When they felt that those were not sufficient to have power over (Purdy, 2012; Hardy \& Phillips, 1998) developers and local councils to shape the DHNS development as per the desires of residents, [DHNS Resident group actionist. Female.45-59] opportunities for communication was progressively built up by establishing statutory and non-statutory resident institutions. Those were the Dickens Heath Working party under the existing Hockley Heath parish council ${ }^{\mathrm{iii}}$ in 1995, upgrading that to a separate Dickens Heath parish council (DHPC) in the year 2000 and Forming Dickens Heath Residents' Action Group (DHRAG) in 2015.

[We wanted some local ... civic identity seen in our engagement with Dickens Heath Development....I don't think that was available with public consultations we had [organised by the local council during 19911997 or so] ...they seemed to rely on people (DHNS residents) just being around rubbing emails and occasionally going to exhibitions and meeting at Solihull...very pleased we [ him and another resident ] set up a Parish Council for Dickens Heath...- good engagement to start with [Pioneer DHNS Resident.Male.45-59]

These resident establishments strategically organised the voices of communities. For instance, DHPC monthly meetings enabled willing residents to meet, discuss and validate local housing issues infrastructure development issues in the central area, community problems, bus service issues, flooding issues, impacts from new housing developments etc. DHRAG was formed to complement these communicative actions giving more flexibility for residents to communicate. We want to do what DHPC really cannot do [DHNS Resident group actionist Female. Over 60]. With much flexibility, 
DHRAG could reach residents "at their doorsteps', speedily advise the residents on issues without waiting for DHPC monthly agenda item [DHNS Resident group actionist. Female.30-44] and engage the left out residents who would otherwise be silent and non-organised. Pioneering DHNS residents often became leaders of these institutions and received power to discursive legitimacy (Purdy, 2012; Hardy \& Phillips, 1998) - the voice of the resident institution represented the shared interest of the DHNS community. This discursive legitimacy per se empowered the resident agency more , compared to them communicating in individual capacities.

These establishments were also strategic in terms of residents accessing power to (financial, human capabilities and skills) resources and (social and professional) networks, further empowering their position at communicative actions. For instance, DHPC was entitled to collect tax precepts from its (resident) members; $£ 70$ per household/year and receive funds allocated from SMBC. DHRAG could collect membership fees and donations from the residents and ward council members etc. Resident members' professional knowledge and skills (in law, planning, finance, housing etc.) were recognised and mobilised to enhance their success at communicative planning. For instance, Chairmen of DHPC over the past had been lawyers, former board members and chair for Solihull Community Housing, SMBC etc. Their professional knowledge was used respectively to understand the technical aspects when dealing with the planning, set forward appropriate arguments strategically in favour of residents, and increase the competency of the meetings and events organised by DHPC or DHRAG. These residents were transforming their social and professional networks with SMBC, charitable trusts and other state institutions for the benefit of DHNS community interest. Furthermore, the discursive legitimacy that DHPC and DHRAG had enabled, provided them with the power to network with other complementary civic local institutions; Solihull ratepayers, local councillors, Campaign to Protect Rural England (Warwickshire), to form alliances at the space of common interest.

Power rationality tension on communication: There was no evidence of these strategic rationalities putting aside any resident taking part in the engagement process. It rather encouraged not-soenthusiastic or non-participant's interests to be taken forward. Nevertheless, instances were found where fundamental tensions arose among these strategic, communicative, and the resident's value rationalities (Brownill \& Carpenter, 2007). The strategic intent of the DHPC and DHRAG is to be "successful" at the planned decision making and their reflexive observation that community interest cannot supersede the interest of national policies; it is the professional resident's opinion that tends to have predominance. For instance, at the public engagement events for the new housing developments (around 2015-2017), which were proposed to develop adjoining greenbelt lands, DHPC and DHARG chose to communicate the technocratic points of professional residents' such as council's errors found in the public consultation processes [DHNS Parish Council, Female. Over 60]. The resident's true subjective interests, such as their fear for the loss of greenery, infrastructure pressure, neighbourhood disturbances etc. was not communicated on the basis that those values don't help to compete [DHNS Parish Council, Male. Over 60] with the interest of market-responsive national planning policies. From the communicative planning point of view, it displaced the 'truthfulness' of the resident's personal interest (dramaturgical - expressive, self-representative emotive knowledge) being informed to the planned decision making; the very intended purpose of communicative planning.

\subsection{Emotive knowledge produced}

As per the SMBC records of public comments for planning applications, 
DHNS residents produced different forms of emotive knowledge (Rydin, 2007) amidst varying power rationalities and motives.

Emotive knowledge by Old Dickens communities at preliminary planning stage: At the DHNS conceptual preliminary planning stage (i.e. from 1991-1997), it had been the residents of Old Dickens Heath hamlet (nearly 200 residents -rural and aged community) who were engaged with the SMBC and developer consortium. They responded with anxiety over possible negative impacts to Old Dickens [SMBC Councillor]. Accordingly, their participation produced empirical knowledge (e.g. their everyday life bonds with Old Dickens Heath and how the proposed developments would distort their rural lifestyles), predictive knowledge (e.g. possibilities of DHNS turning into rat-run after its development) and normative knowledge (e.g. DHNS Master Plan should design internal roads narrow to preserve the rural atmosphere of the village). Respectively, this knowledge was relevant to inform planning about the contemporary social, spatial context of the proposed DHNS site, future living conditions of DHNS and how they prefer to see DHNS developed.

Emotive knowledge by early settled DHNS residents: The most prominent next stage of community engagement was developing DHNS's central parts with town housing and apartments during 2000-2012. During this time, the newly settled residents at the outer zone of DHNS strongly engaged in public consultation to ensure the council and developers deliver what was promised in the initial master plans. In the light of this, the communities communicated their everyday life experiences in DHNS (often negative or problematic aspects) (e.g. traffic and parking conditions, problems of not having bus service, doctors, shops, library to DHNS etc.), which produced empirical (experiential) knowledge. The outcome state of initial plans implemented for DHNS was informed to the planning; the deviations between plan expectations and actual outcomes in a feedback form. Some empirical (experiential) knowledge challenged the previously held normative knowledge produced by the Old Dickens residents (Klasic \& Lubell, 2020; Innes \& Booher 1999). Examples include, how new residents' lifestyles and commuting networks were negatively affected by designing internal roads narrowly ${ }^{\mathrm{IV}}$ in adherence with the early Old Dickens residents' views.

Similarly, the residents' communication about their experiences (experiential) knowledge) validated common issues related to the DHNS housing environment and led them to suggest solutions (normative knowledge). For instance, residents claimed that DHNS should have a dedicated bus service connecting to Solihull to solve public transport issues partly.

Moreover, the changes to the national planning policy in England around 2000 (i.e. Planning Policy Guidance 3, 2000) promoted densifying of build-up lands; as a result, the planning applications for the DHNS central area almost doubled the housing numbers, compared to what was planned in the DHNS master plan. Regarding the tensions over such policy changes, the residents' communication also produced predictive and process knowledge concerning planning and societal interactions. For instance, predicting how new densified housing numbers would let the market bring in households with different lifestyles (societies), how the existing residents' lifestyle patterns and housing environment would be affected, the infrastructure impacts to them when housing numbers increased more than planned and so on.

Emotive knowledge since the establishment of resident organisations: 2012 and thereabouts, DHNS reached the stages of further growth. Primarily, owing to the liberated or market-responsive national planning reforms (particularly, NPPF, 2012), DHNS tend to have many planning applications coming forward to 
develop its safeguarded sites earlier than it was planned. As highlighted previously, DH residents established resident organisations - DHPC and DHRAG particularly communicating against these market pressures. The residents' sharing living experiences in DHNS during the time; emphasis of their encounters with infrastructure issues, anti-social behaviours by youngsters, newly established rented community in apartment housing and people commute to DHNS from outside areas, increase of crimes, lifestyle issues, continued to produce empirical (experiential) and social process knowledge of DHNS relevant to the time. Similarly, their reactions (mainly negatively) to new planning applications also continued to produce predictive knowledge regarding the new development impacts on future traffic, highway, flooding, apartment management in DHNS.

The solutions suggested to some of the existing and predicted problems (e.g. new housing should include suitable designs for the growing elderly population in DHNS, a Multi-Unit Game Area should be established for youngsters growing in the settlements) produced normative knowledge on housing and neighbourhood service mix for DHNS after 2010. DHPC and DHRAG being established as the resident's first level, but with a wider communication platform among residents, enabled them to validate the shared housing environmental issues and solutions [Pioneer DHNS Resident.Male.45-59] to them from residents' perspective. Moreover, the professional residents commented how planning decisions based on national policy (i.e NPPF, 2012) made an impact on DHNS residents [Pioneer DHNS Resident.Female.45-59]. These produced planning process knowledge. Local council's non-adherence when put policy into practice, the resident's interpretation of NPPF policy criteria; what should be the Objectively Assessed Housing Needs for DHNS and the arguments as to how sustainability should be understood when it comes to planning applications are some other examples of such knowledge.

\subsection{Consensus building for planned decision making}

Consensus-building (plan decision making) of varying emotive knowledge types together with knowledge of other actors (primarily of development consortium and the council) found to have been governed in different forms when planning DHNS.

Consensus building at preliminary planning applications: The preliminary planning approval for DHNS [decision on housing location and numbers] happened during 1991; whether the aimed housing numbers to be allocated to new DHNS, or an alternative location such as Cranmore Widney [an already developed settlement $2 \mathrm{Km}$ away from DHNS] was governed in the pluralist democracy form.

"Having more than three thousand residents and [SMBC] council members opposing for new housing overdevelopment impacts, we couldn't allocate more housing numbers to Cranmore Widney. The councillors and residents said, 'never again.' So we had to look for new locations such as DHNS." [DHNS Planner, SMBC Council].

Residents of Old Dickens Heath also produced similar public comments (emotive knowledge) objecting to new housing development coming near them, but the voice of three thousand residents in Cranmore Widney and the SMBC local councillors held power over the smaller resident group at Old Dickens. Consequently, housing was chosen to be developed in greenbelt land adjoining Old Dickens Heath village, instead of an extension to the existing settlement area. Towards the year 2000 and thereabouts, such preliminary planning application decision to further allocate land for housing in DHNS turned out to be governed through a mix of corporatism and criteria driven forms. 
The land intensification led to national planning policy in 2000 (i.e. PPG 3, 2000), and subsequent market-responsive national planning policy (i.e. NPPF, 2012, 2019) urged local councils to be responsible for meeting housing shortages in the region at affordable levels. These policies thus enabled market actors to exert a greater agency (power over) over other actors (Gunder, 2010; Purcell, 2009) at the planning application stages. In that context, despite DHNS residents' power to communicate was developed through establishing DHPC, DHRAG, networking with other community organisations, the public comments that conflicted with market actors (i.e. developers) had limited power to influence the plan decision (Gunder, 2010; Purcell, 2009).

Consensus building on detailed design and development: The consensus building at this stage was about decisions regarding DHNS master plans, detail planning applications and construction. Unlike the preliminary planning application stage, consensus-building has been governed relatively by the community's shared emotive knowledge (inclusionary argument style). Examples include DHNS master plans to retain its rural character ${ }^{\text {iv }}$ by designing internal circulation roads narrowly, as proposed by DH working party (around 1994 and thereabouts), DHNS Stage III site (in 2015) accommodating housing layouts and sizes suitable for increasing elderly in DHNS and Multi Area Games Unit (MUGA) to provide recreation for the increasing number of youth as proposed by DHPC. The council's and market actor's desire to win community support which otherwise would be problematic when constructions begin for DHNS [DHNS Developer Consortium Member] held power relations among planners, market actors and the community closer to a neutral level (Habermas, 1984).

Besides, instances were also found at this stage where residents reached a consensus to resolve housing environment issues by themselves - participatory actions; DHNS bus service, health and community facilities, landscaping of common areas and commencing neighbourhood plan preparation for DHNS. The voluntary community leadership and continuous communicative actions practised at DHPC and DHRAG made the residents efficient and effective representatives of issues, and enabled them to explore leadership, solutions, and resolve problems by themselves. The local council acted only as facilitators to those participatory solutions providing relevant approvals.

However, detailed design decisions taken in a clientelism form of governance were also found at few instances. Sites that developed during 2014 onwards, where "developers separately negotiated with few adjoining landowners and gave away gas and electrical lines" [SMBC Planner] were not representative of the shared interests of the DHNS community as a whole, but pleasing residents by patronage who otherwise be objecting the development (Cooke and Kothari, 2001).

Consensus building on neighbourhood management: After development, the SMBC council is bound to be responsible for managing the public realm and public spaces of DHNS, except for the central parts privatised and operated by Dickens Heath Management Company on service fee charges from the respective residents. Having to undertake the neighbourhood management of DHNS through local authority budgets, the communications by DHPC's, DHRAG's or by individual residents' regarding any neighbourhood management matter were entirely governed through the deductive logic of regulatory provisions (criteria-driven approach).

An SMBC council's planner, answering the question, how would SMBC take into account day-to-day management and maintenance issues brought forward by the DHNS residents? stated; it is based on evidence to support the view and the requirement... Those would be measured against the policy in the local plan or with 
other policies" [DHNS Planner, SMBC Council]. On this basis, residents' interests become valid for plan decision making if those complies with the existing policy.

However, instances were found closer to communicative planning (inclusionary argument style) where the residents' participatory actions were mobilised to accomplish their shared visions for DHNS's neighbourhood management; participatory actions for the maintenance of roads, kerbs, pumps, lifts, security, village green in the central area and beautification of the rest of the DHNS. Those were instances in which the residents had mobilised their own resources; DHPC precepts, service charge fees by central area residents and voluntary labour without relying much on external resources (such as council's budgetary allocations).

\section{Conclusion}

As contemporary literature highlights, the 'ideal' potential for communicative planning exists when (i) local communities produce expressive, self-representative and subjective emotive knowledge (Habermas, 1984) that has varying relevance (Rydin, 2007), (ii) different rationalities for power in the communicative process are recognised and mobilised (Brownill \& Carpenter, 2007; Albrechts, 2003) and used as a modality of change (Foucault, 1984, 1980) and (iii) plan decision making is governed in the mode of inclusionary argumentation (Healey, 2006). This study aimed to investigate the extent to which this ideal can be reached in practice in the context of housing estate development in England. DHNS as a case study demonstrates that communicative planning has some potential within the housing estate development process in England to form 'sustainable' or 'meaningful' planned housing outcomes.

In DHNS, such meaningful outcomes were found to be accrued in the areas of incorporating residents' vision into housing estate design, establishing the functioning of neighbourhood services (e.g. bus connectivity, doctors, dentist, community centre, library), investment and management of streetscaping, landscaping and other beautification of the locality and establishing residents-led-institutions which could further empower them to communicate their experiences, build civic identities and recognise their shared interests for the neighbourhood.

DHNS residents were representative of a 'strong' community, primarily White British, educated and engaged in professional and administrative jobs. The DHNS residents built their power in communication as a modality of change (Wolff, 2020; Brownill \& Carpenter, 2007; Albrechts, 2003, Foucault, 1984, 1980) to better order the housing estate development outcomes. The communicative rationalities provided to residents by planning legislation and Solihull Metropolitan Borough Council empowered them to bring synergic effects towards communication; for communities to build their value, instrumental and strategic rationalities in communication. In other words, the residents' initial communication via given platforms led them to identify and develop reasoning over time for housing estate development issues, recognise pioneering leadership, discover and access possible resources, and recognise strategies and institutions to voice residents' shared interests.

DHNS residents have been progressively generating emotive knowledge of varying relevance. Those informed planned decision making was about residents' vision and expected living arrangements at DHNS, predictions and causal relationships between planning and market process and DHNS residents' experiences. Even though much potential was portrayed for communicative planning regarding residents' access to power and production of emotive knowledge, not all decisions on the DHNS development process embraced communicative planning approaches. 
The inclusionary argument - the mode of governance for consensus-building those attributes well with communicative planning was found to be possible only at the detailed design stages of the DHNS development. At these instances, the power relations of actors were held at a relatively neutral level (Habermas, 1984); market actors and local planning wanting to have community support to take the development forward.

In other instances, the actors having the power to resources (i.e. often market actors) showed to exert a greater agency in consensus building (decision making) (Gunder, 2010; Purcell, 2009, Cooke \& Kothari, 2001). When land, housing, and neighbourhood development is to be delivered through markets, and national planning policies are market responsive, the interests of the development consortium tend to be in a favourable position at the preliminary planning approval decisions (Gunder, 2010; Purcell, 2009). Instances were also found where the tyranny of participation manipulates the local knowledge to be compatible with bureaucratic planning, leading to patronage type relationships (Cooke \& Kothari, 2001) - professionally occupied resident's opinion dominating other residents when communicating with the local council (SMBC), and a few residents communicating with developers for customised benefits at the detail design stages of some planning applications.

When DHNS neighbourhood management was financed through local authority (state) budgets, the decision making would follow criteria given in respective state policies. The case study demonstrates other instances where the residents' emotive knowledge is incorporated into decision making at the development and neighbourhood management stages of DHNS. Those were when the residents themselves mobilised their own resources (leadership. new ideas and capabilities, network and new relationships, finance) to solve respective issues via participatory actions (Wolff, 2020; Brownill \&
Carpenter, 2007; Albrechts, 2003, Innes \& Booher, 1999). In these instances, planners were mere facilitators of implementing those decisions.

Furthermore, one-time residents' shared vision for DHNS design differed from the later settled residents', which would mean that communicative planning cannot guarantee fixed 'meaningful' and 'sustainable' solutions (Perera, 2019, Innes $\&$ Booher, 1999). Even the ideal shared understanding brought by inclusionary argument would need revising through subsequent community planning actions. These findings steer several implications for communicative planning theory, policy and practice for housing. In the context of housing estate developments, residents (i) building up their power to authority, discursive legitimacy networks and resources and, (ii) continuous engagement in the communicative actions to learn about the issues, to see new social orders, articulating those issues to others, find leadership and capabilities over time, can lead communicative planning to accrue positive effects. However, market conditions (Gunder, 2010; Purcell, 2009), power (Habermas, 1984) and patronage relationships (Cooke \& Kothari, 2001) among actors in the process, that are hardly inevitable, certainly hinder the communicative planning from reaching its fullest potential. Yet again, as shown in the case study, the process may come across conditions favourable for communicative planning to reach its optimal potentials. DHNS case highlights that such conditions are when the power relations of all actors in the communicative process become closer to a neutral level (Habermas, 1984) or residents having resources to solve the issue by themselves. Hitherto 'meaningful' or 'sustainable' solutions that communicative planning can bring about are time-bound are challenged as circumstances change. Thus, communicative planning and building shared understanding needs to be an ongoing planning approach rather than one-time activity at development. 


\section{Acknowledgement}

The Commonwealth Scholarship

Commission, United Kingdom, is acknowledged for funding support for the research project on which this paper is based. The Centre for Real Estate Studies University of Sri Jayewardenepura, Sri Lanka, is acknowledged for assistance provided in the preparation of this paper.

\section{References}

Albrechts, L., (2003). Planning and power: towards an emancipatory planning approach. Environment and Planning C: Government and Policy, 21(6), 905-924. https://doi.org/10.1068/c29m

Alexander, R. (2008). Education for All, The Quality Imperative and the Problem of Pedagogy. CREATE Pathways to Access. Research Monograph, 20. Available at http://www.createrpc.org/pdf_documents/PTA20.pdf [15 December 2020]

Ansell, C., \& Gash, A. (2008). Collaborative governance in theory and practice. Journal of public administration research and theory, 18(4), 543-571. https://doi:10.1093/jopart/mum032

Barker, K. (2006). Barker review of land use planning: Final report, recommendations. The Stationery Office. London: HM Treasury. Available at https://assets.publishing.service.gov.uk/government/uploads/system/uploads/attachment_data/file/228605/01 18404857.pdf [last accessed 14 December 2020]

Booher, D. E., \& Innes, J. E. (2002). Network power in collaborative planning. Journal of planning education and research, 21(3), 221-236. https://doi.org/10.1177/0739456X0202100301

Brownill, S. (2009). The dynamics of participation: modes of governance and increasing participation in planning. Urban Policy and Research, 27(4), 357-375. https://doi.org/10.1080/08111140903308842

Brownill, S., \& Carpenter, J. (2007). Participation and planning: Dichotomies, rationalities and strategies for power. Town Planning Review, 78(4), 401-429.

Bryman, A. (2016). Social research methods. Oxford university press.

Cooke, B., \& Kothari, U. (Eds.). (2001). Participation: The new tyranny? Zed books.

Florini, A. (2019). Collaborative governance. Handbook of Inclusive Innovation.

Flyvbjerg, B. (2006). Five misunderstandings about case-study research. Qualitative Inquiry, 12(2), pp.219245.

Forester, J. (1989). Planning in the face of power, University of California Press. Berkeley CA.

Forester, J. (1999). The deliberative practitioner: Encouraging participatory planning processes. MIT Press.

Foucault, M. (1980). Power/knowledge: Selected interviews and other writings, Colin Gordon, ed. pp. 109133. New York: Pantheon Books.

Foucault, M. (1984). The Foucault reader. New York: Pantheon. Friedmann, J. (1987) Planning in the Public Domain: from Knowledge to Action (Princeton, NJ: Princeton University Press).

Gunder, M. (2010). Planning as the ideology of (neoliberal) space. Planning Theory, 9(4), pp.298-314. https://doi.org/10.1177/1473095210368878

Habermas, J. (1979). Communication and the evolution of society. Boston, Mass.: Beacon Press

Habermas, J. (1981). New social movements. Telos, 1981(49), pp. 33-37. 
Habermas, J. (1984). The theory of communicative action (Vol. 2). Beacon press.

Hardy, C., \& Phillips, N. (1998). Strategies of engagement: Lessons from the critical examination of collaboration and conflict in an interorganizational domain. Organisation science, 9(2), 217-230.

Healey, P. (1999). Institutionalist analysis, communicative planning, and shaping places. Journal of planning education and research, 19(2), 111-121. https://doi.org/10.1177/0739456X9901900201

Healey, P. (2006). Collaborative planning: Shaping places in fragmented societies. 2nd ed. New York: Palgrave Mcmillan.

Healey, P. (2015). Civic capacity, place governance and progressive localism. Reconsidering localism, 105125.

Innes, J. E., \& Booher, D. E. (1999). Consensus building and complex adaptive systems: A framework for evaluating collaborative planning. Journal of the American planning association,65(4), 412-423. https://doi.org/10.1080/01944369908976071

Inch, A. (2015). Ordinary citizens and the political cultures of planning: In search of the subject of a new democratic ethos. Planning Theory, 14(4), 404-424. https://doi.org/10.1177/1473095214536172

Innes, J. E., \& Booher, D. E. (2004). Reframing public participation: strategies for the 21st century. Planning theory \& practice, 5(4), 419-436. https://doi.org/10.1080/1464935042000293170

Johansson, R. (2007). On case study methodology. Open House International, 32(3). pp.48-54. https://doi.org/10.1108/OHI-03-2007-B0006

Khakee, A., Barbanente, A., \& Borri, D. (2000). Expert and experiential knowledge in planning. Journal of the Operational Research Society, 51(7), 776-788. https://doi.org/10.1057/palgrave.jors.2600841

Klasic, M., \& Lubell, M. (2020). Collaborative governance: from simple partnerships to complex systems. In Handbook of US Environmental Policy. Edward Elgar Publishing.

Locander, W., Sudman, S. and Bradburn, N. (1976). An investigation of interview method, threat and response distortion. Journal of the American Statistical Association, 71(354), pp.269-275.

Leishman, C., Frey, J., \& McGreal, S. (2020). Micro-economics of housing supply.

Løkke, A. K., \& Sørensen, P. D. (2014). Theory Testing Using Case Studies. Electronic Journal of Business Research Methods, 12(1).

Lukes, S. (1986). Power. NY: NYU Press.

Mihas, P., (2019). Qualitative data analysis. In Oxford Research Encyclopedia of Education.

Natarajan, L. (2017). Socio-spatial learning: A case study of community knowledge in participatory spatial planning. Progress in Planning, 111, 1-23. https://doi.org/10.1016/j.progress.2015.06.002

Newman, J. (2001) Understanding Governance (Bristol: Policy Press) cited in Brownill, S., 2009. The dynamics of participation: modes of governance and increasing participation in planning. Urban Policy and Research, 27(4), pp.357-375.

Office for National Statistics (estimate), (2019). (updated). Available at https://www.ons.gov.uk/peoplepopulationandcommunity/populationandmigration/populationestimates/bulleti ns/annualmidyearpopulationestimates/mid2019estimates [last accessed 11/14/2020].

Perera, T.G.U.P. (2019) Achieving sustainable housing affordability through an institutionalist approach to communicative planning: a case study of a new settlements and sustainable urban extensions in England (Doctoral dissertation, University of Birmingham).

Perera, U., \& Mensah, C. A. (2019). Conceptualising sustainability in the real estate development process. Sustinere: Journal of Environment and Sustainability, 3(1), 1-14. https://doi.org/10.22515/sustinere.jes.v3i1.62 
Preece, J., Hickman, P., \& Pattison, B. (2020). The affordability of "affordable" housing in England: conditionality and exclusion in a context of welfare reform. Housing Studies, 35(7), 1214-1238. https://doi.org/10.1080/02673037.2019.1653448

Purcell, M. (2009). Resisting neo-liberalisation: communicative planning or counter-hegemonic movements? Planning Theory, 8(2), pp. 140-165. https://doi.org/10.1177/1473095209102232

Purdy, J. M. (2012). A framework for assessing power in collaboration governance process. Public Administration Review, 72(3), pp. 409-417. https://doi.org/10.1111/j.1540-6210.2011.02525.x

Ragin, C.C. (2004). Turning the tables: how case-oriented research challenges. Rethinking social inquiry: Diverse tools, shared standards, 123.

Ratcliffe, J., Stubbs, M., \& Keeping, M. (2009). Urban planning and real estate development. Routledge.

Rudlin, D., \& Falk, N. (2009). Sustainable Urban Neighbourhood: building the 21 st century home. Routledge.

Rydin, Y. (2007). Re-examining the role of knowledge within planning theory. Planning theory, 6(1), pp.5268. https://doi.org/10.1177/1473095207075161

Rydin, Y., Bleahu, A., Davies, M., Dávila, J. D., Friel, S., De Grandis, G., ... \& Wilson, J. (2012). Shaping cities for health: complexity and the planning of urban environments in the 21st century. The lancet, 379(9831), 2079-2108.

Solihull Metropolitan Borough Council. (undated). Available at http://www.solihull.gov.uk/Resident/Libraries/Local-family-history/localhistory/dickensheathhistory. [last accessed on 09 October 2019].

Town and Country Planning Association (2007). Best Practices in Urban Extensions and New Settlements, Available at https://www.tcpa.org.uk/Handlers/Download.ashx?IDMF=55474980-8f1e-4298-a86f5fec267dc530, [last accessed 03 November 2019].

Verster, B. (2020) Reimagining collaboration in urban planning through a social practice lens: Towards a conceptual framework. Town and Regional Planning, 76, pp.86-96. http://dx.doi.org/10.18820/24150495/trp76i1.7

Villanueva, R.C., Mantripragada, N., \& Thompson, A. (2017): Influence of land-use on the abundance of soil mineral reactivity at the Calhoun CZO. University of Georgia Young Scholars Conference, Athens, GA.

Vos, R. O. (2007). Defining sustainability: a conceptual orientation. Journal of Chemical Technology and Biotechnology, 82, 334-339. https://doi.org/10.1002/jctb.1675

Williams, J. B., Jose, R., Moobela, C., Hutchinson, D. J., Wise, R., \& Gaterell, M. (2019). Residents' perceptions of sustainable drainage systems as highly functional blue green infrastructure. Landscape and Urban Planning, 190, 103610. https://doi.org/10.1016/j.landurbplan.2019.103610

Wolff, A. (2020). Planning culture-dynamics of power relations between actors. European Planning Studies, 28(11), 2213-2236.

World Bank. "Urban population.” World Development Indicators, The World Bank Group, 2020, Available at https://data.worldbank.org/indicator/SP.URB.TOTL.IN.ZS [last accessed 13 December 2020]

Yin, R.K. (2014). Case study research: Design and methods. Los Angeles, London, New Delhi, Singapore Washington DC: Sage.

Zaidan, E., \& Abulibdeh, A. (2020). Master Planning and the Evolving Urban Model in the Gulf Cities: Principles, Policies, and Practices for the Transition to Sustainable Urbanism. Planning Practice \& Research, 1-23. https://doi.org/10.1080/02697459.2020.1829278 